- 48 
Digitized by the Internet Archive in 2011 with funding from University of Toronto 



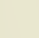




\section{CONTRIBUTIONS}

OF THE

ROYAL ONTARIO MUSEUM OF ZOOLOGY AND PALAEONTOLOGY

No. 33

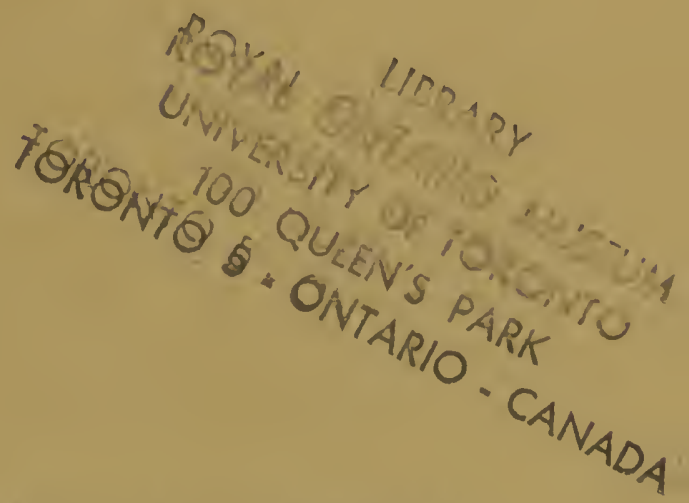

NOTES ON THE BOBCATS (LYNX RUFUS) OF EASTERN

NORTH AMERICA WITH THE DESCRIPTION OF A NEW RACE

By

Randolph L. Peterson and Stuart C. Downing

TORONTO

APRIL 8, 1952 

NOTES ON THE BOBCATS (LYNX RUFUS) OF EASTERN NORTH AMERICA WITH THE DESCRIPTION OF A NEW RACE 



\section{CONTRIBUTIONS}

\section{OF THE}

ROYAL ONTARIO MUSEUM OF ZOOLOGY AND PALAEONTOLOGY

No. 33

NOTES ON THE BOBCATS (LYNX RUFUS) OF EASTERN NORTH AMERICA WITH THE DESCRIPTION OF A NEW RACE

By

Randolph L. Peterson and Stuart C. Downing

TORONTO

APRIL 8, 1952 
Printed in Canada by University of Toronto Press 


\title{
NOTES ON THE BOBCATS (LYNX RUFUS) \\ OF EASTERN NORTH AMERICA WITH \\ THE DESCRIPTION OF A NEW RACE
}

\author{
by \\ Randolph L. Peterson and Stuart C. Downing
}

Is THE course of reviewing the distribution and taxonomic status of bobcats in eastern Canada, it has become apparent that a hitherto undescribed subspecies exists in the western Great Lakes region which may be known as:

\section{Lynx rufus superiorensis subsp. nov.}

Type specimen. Middle-aged adult male (skin and complete skeleton) No. 20947, Royal Ontario Museum of Zoology and Palaeontology, collected on April 4, 1951.

Type locality. McIntyre Township, near Port Arthur, Ontario.

Geographic distribution. In Ontario, it now extends into southwestern Algoma and western Manitoulin Island districts and from southeastern Manitoba across the western portion of the Province to at least as far north and east as the Kenogami River. In the United States, it occurs in the upper peninsula of Michigan, west across Wisconsin and Minnesota (see fig. 2). The western and southern limits, both past and present, are as yet unknown.

Skull characters. In adults, Lynx rufus superiorensis differs from L. r. rufus in the shape of the dorsal contour of the cranium, that of rufus being a more-or-less symmetrical curve, while in the new race the symmetry is usually interrupted by a more inflated supra-orbital region. When fully adult skulls of the two races are placed on their dorsal surfaces on a flat, level table, the palate of superiorensis usually lies in a horizontal plane while that of rufus inclines forward (see fig. 4).

It also differs from rufus in having a relatively smaller upper third premolar. When the greatest width of $\mathrm{PM}^{3}$ was expressed as a percentage of the greatest width of the palate (including toothrows) a statistically significant difference was found in the specimens examined (fig. 1, A and B). In 11 adult males of superiorensis the width of $\mathrm{PM}^{3}$ averaged $9.49 \pm .168$ per cent 


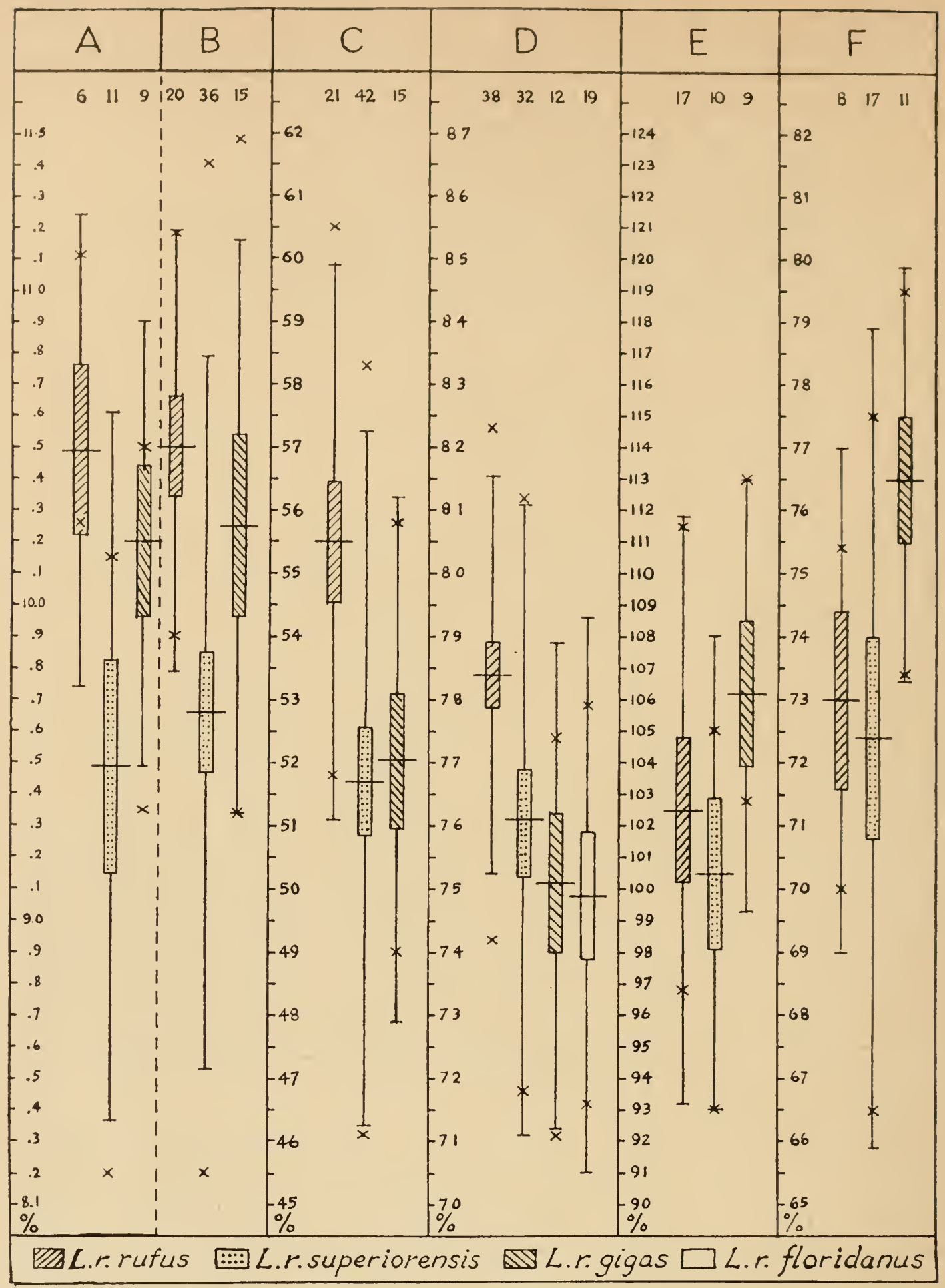

FIG. 1. Variation in skull characters of eastern bobcats. Median horizontal bars represent the mean, the central enclosed areas represent two standard errors $\left(S E=\frac{S}{\sqrt{N}}\right)$ and the median vertical lines represent two standard deviations on either side of the mean $\left(S=\sqrt{\frac{\Sigma x^{2}}{N-1}}\right)$. Figures above indicate number of specimens in each sample and $\mathrm{X}$ represents observed limits.

A. Relative width of $\mathrm{PM}^{3}$ expressed as percentage of the greatest width of the palate (including toothrows), in adult males only.

B. The same ratio as A but including both sexes of all specimens with fully erupted permanent teeth.

C. Shape of $\mathrm{PM}^{3}$ expressed as a ratio of its greatest width to its greatest length, which includes both sexes of all specimens examined with fully erupted dentition.

D. Ratio of the zygomatic breadth to the condylobasal length including both sexes with adult dentition.

E. Ratio of the length of the palate to the greatest width of the palate (including toothrows) in adult males only.

F. Ratio of the length of the maxillary toothrow (including canines) to the width of the palate in fully adult specimens of both sexes. 


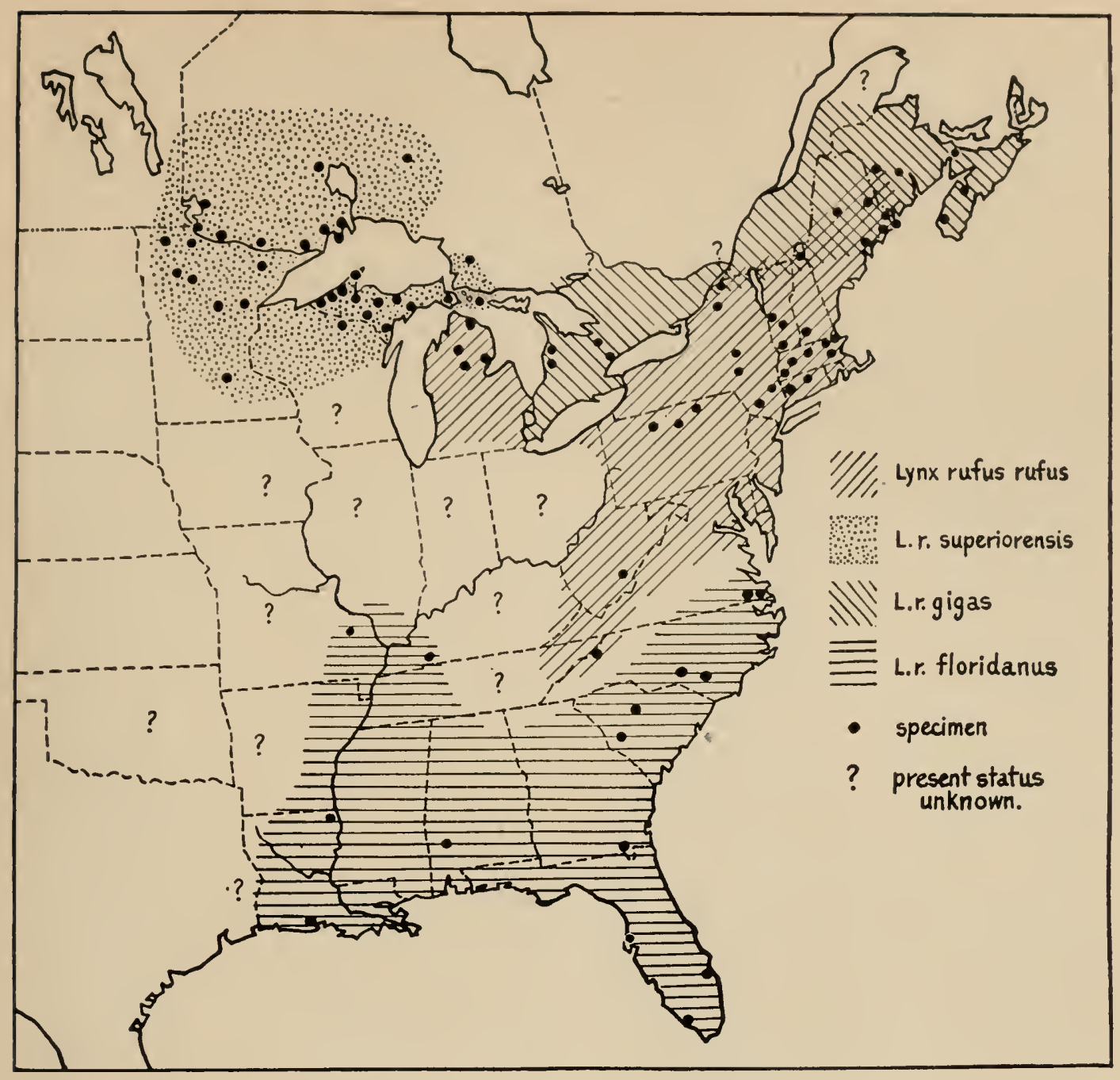

FIG. 2. Distribution of bobcats in eastern North America.

of the palate width, while in six similar rufus specimens the average was $10.49 \pm .133$. This character appears fairly consistent in both sexes and in all ages, subsequent to the development of the adult dentition. This difference was corroborated when all specimens of the above classes (36 superiorensis and 20 rufus) were grouped together to provide a larger sample (fig. 1, B).

The shape of the $\mathrm{PM}^{3}$ tends to be relatively narrower in superiorensis, the width averaging $51.7 \pm .42$ per cent of its length in 42 animals with adult dentition, while 21 similar rufus averaged $55.5 \pm .48$ per cent (fig. $1, \mathrm{C}$ ). Since a certain amount of individual variation in this and the following character was observed, particularly in upper peninsula of Michigan specimens, these are most useful as characteristics of populations, rather than of individual specimens. 


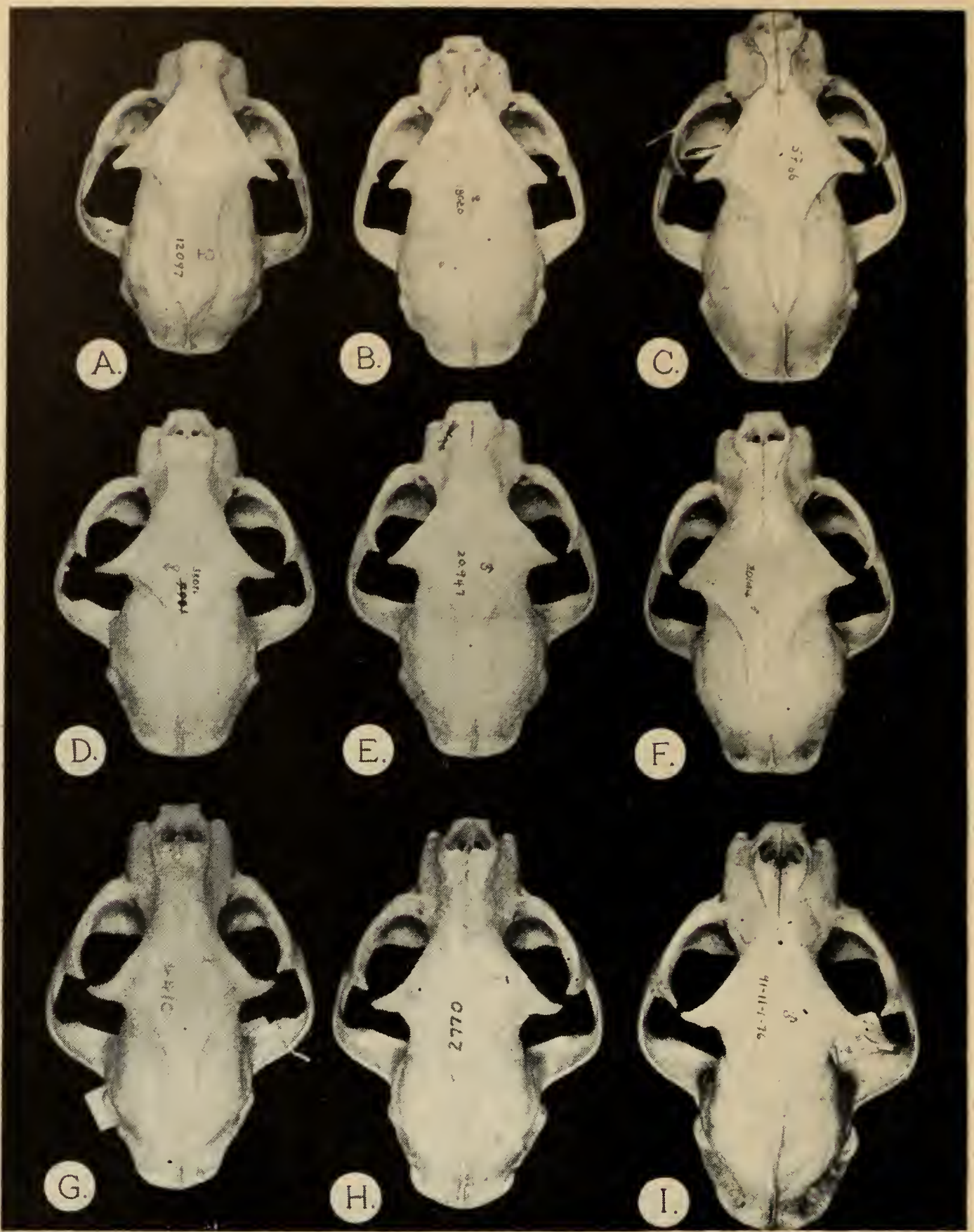

FIG. 3. Skulls (dorsal view) of northeastern bobcats.

A. Female, L. r. rufus from Merrimack Co., N.H. (U. Kans.).

B. Female, L. r. superiorensis from Sifton Twp., Rainy River Dist., Ont. (R.O.M.Z.P.).

C. Female, L. r. gigas from Digby Co., N.S. (M.C.Z.).

D. Male, L. r. rufus from Merrimack Co., N.H. (M.C.Z.).

E. Male, L. r. superiorensis (type). Greatest length $132.4 \mathrm{~mm}$.

F. Male, L. r. gigas from Cumberland Co., N.S. (N.M.C.).

G. Old adult male, L. r. rufus from Warren Co., N.Y. (N.Y.S.M.).

H. Old adult male [?], L. r. superiorensis from Minn. (M.M.N.H.).

I. Old adult male, L. r. gigas from Bruce Co., Ont. (R.O.M.Z.P). 


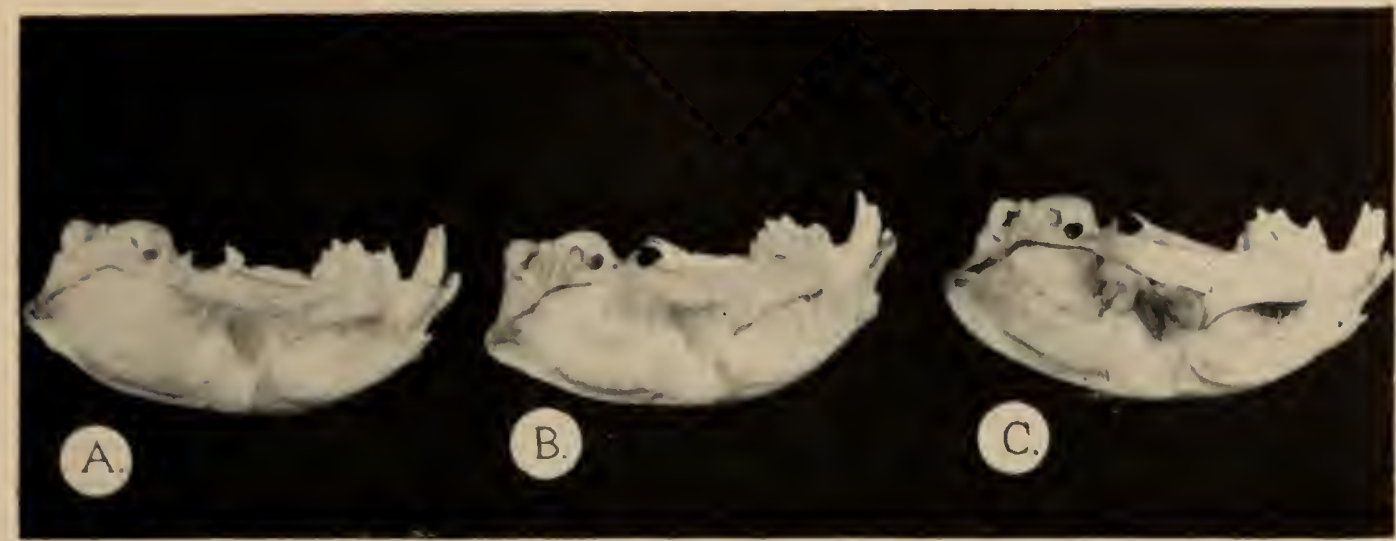

Fig. 4. Skulls of old adult northeastern bobcats, lateral view, illustrating dorsal contour.

A. L. r. rufus, no. 4410 ; B. L. r. superiorensis, no. 2770

(greatest length $140.6 \mathrm{~mm}$. ); C. L. r. gigas no.91-11-1-76.

The zygomatic width averages relatively narrower in superiorensis, $76.1 \pm .44$ per cent of the condylobasal length in 32 individuals, compared to $78.4 \pm .25$ per cent in 37 rufus (figs. 1 , $\mathrm{D} ; 3$ and 5 ).

The new race differs from $L . r$. gigas in having a relatively wider and shorter palate in mature adults. The length of the palate averaged $100.5 \pm 1.18$ per cent of the greatest width of the palate (including toothrows) in 10 adult males, compared to $106.2 \pm 1.14$ per cent for nine similar gigas (fig. 1, E). This difference is also demonstrated when the length of the maxillary toothrow is compared to the greatest width of the palate in fully adult specimens (fig. 1, F). The relative width of $\mathrm{PM}^{3}$ compared to the width of the palate is also greater in gigas (fig. 1, A and B) although the actual shape is essentially the same as that of superiorensis.

The new race, as well as rufus, gigas and possibly floridanus, differs from L. $r$. pallescens and other western races (especially baileyi, californicus but possibly less so from fasciatus) in the structure of the auditory bullae. As pointed out by Merriam (1890, p. 80) in his description of baileyi, "... a distinct sulcus marks the line of attachment of the septum which separates the tympanic chamber from the inner chamber." In the eastern races the tympanic chamber is relatively smaller and is largely enclosed by the capsular portion of the rest of the bulla, thus making the line of division between the chambers indistinct except in young animals. In pallescens the tympanic chamber is distinctly larger than in superiorensis and projects beyond the anterior end of the bulla proper. In the western races 


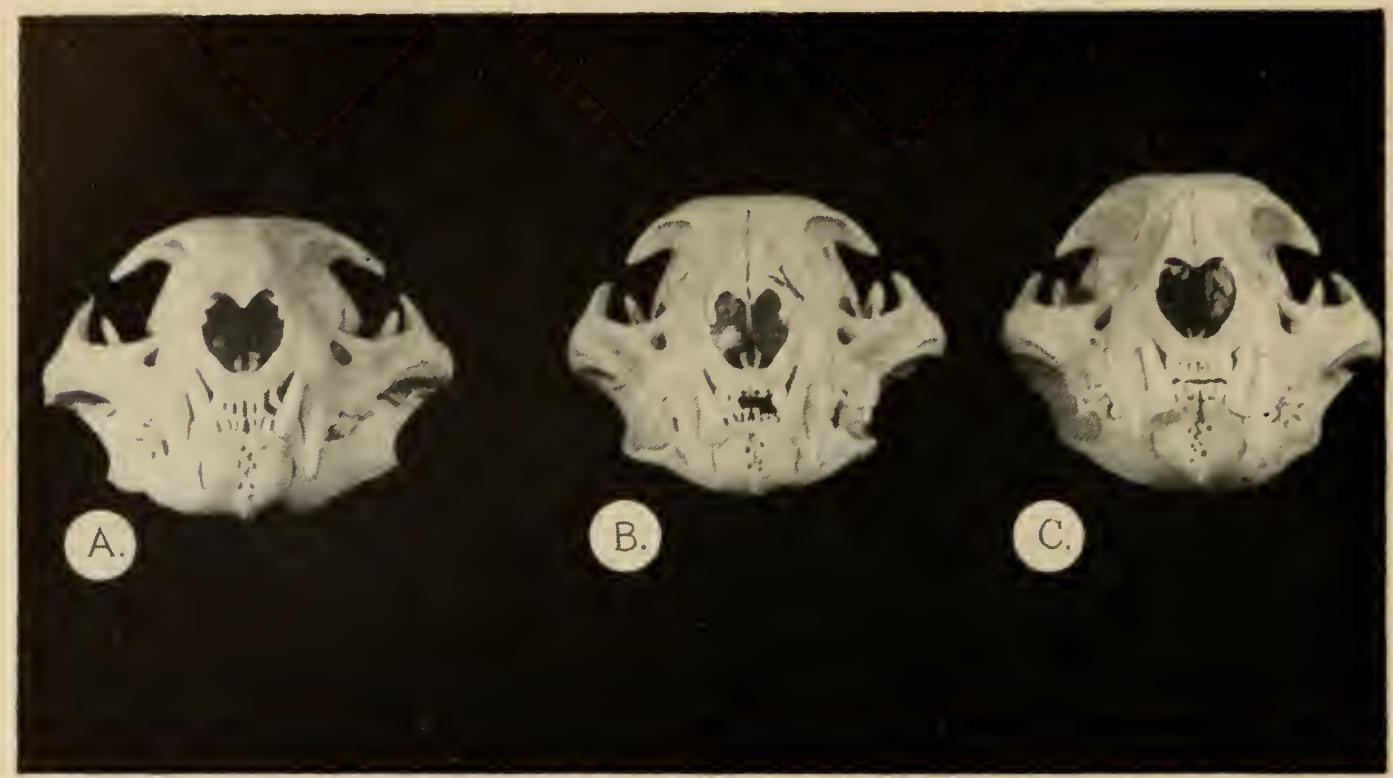

Fig. 5. Anterior view of northeastern male bobcat skulls.

A. L. r. rufus, no. 42085; B. L. r. superiorensis (type);

C. L. r. gigas, no. 20144.

examined, this particular character approaches that of $L$. canadensis. We have found this character to be a useful one for separating the latter from the eastern bobcats.

Other characters. In body size, available measurements indicate that, with animals of roughly comparable age, the new race is intermediate between that of rufus and gigas. The average total length of seven males is $948.0 \mathrm{~mm}$. (890-1015) compared with 876.3 (810-946) for six rufus and 1030.5 (937-1252) for six gigas (see table II). Seven females average $861.4 \mathrm{~mm}$. (800-900) while seven rufus specimens average 823.0 (800-855). A similar trend is indicated by the weights of the heaviest individuals among the above-males, rufus 35.0 lbs., superiorensis 41.0 lbs., gigas 68.5 lbs.; females, rufus $21.5 \mathrm{lbs}$. and superiorensis 27.0 lbs.

In pelage colour and markings we find such an extreme range of variation in the skins available for study that we can find no constant pelage character by which any of the eastern races can be distinguished with certainty. Variations which may be correlated with the age of the animal, or which may be seasonal, sexual, individual or possibly genetic, are further complicated by changes brought about in various tanning processes and by aging as museum specimens.

A great range of variation is shown by our series of 35 skins of superiorensis (see fig. 6). In this series we find that winter and summer specimens are readily distinguishable by general 


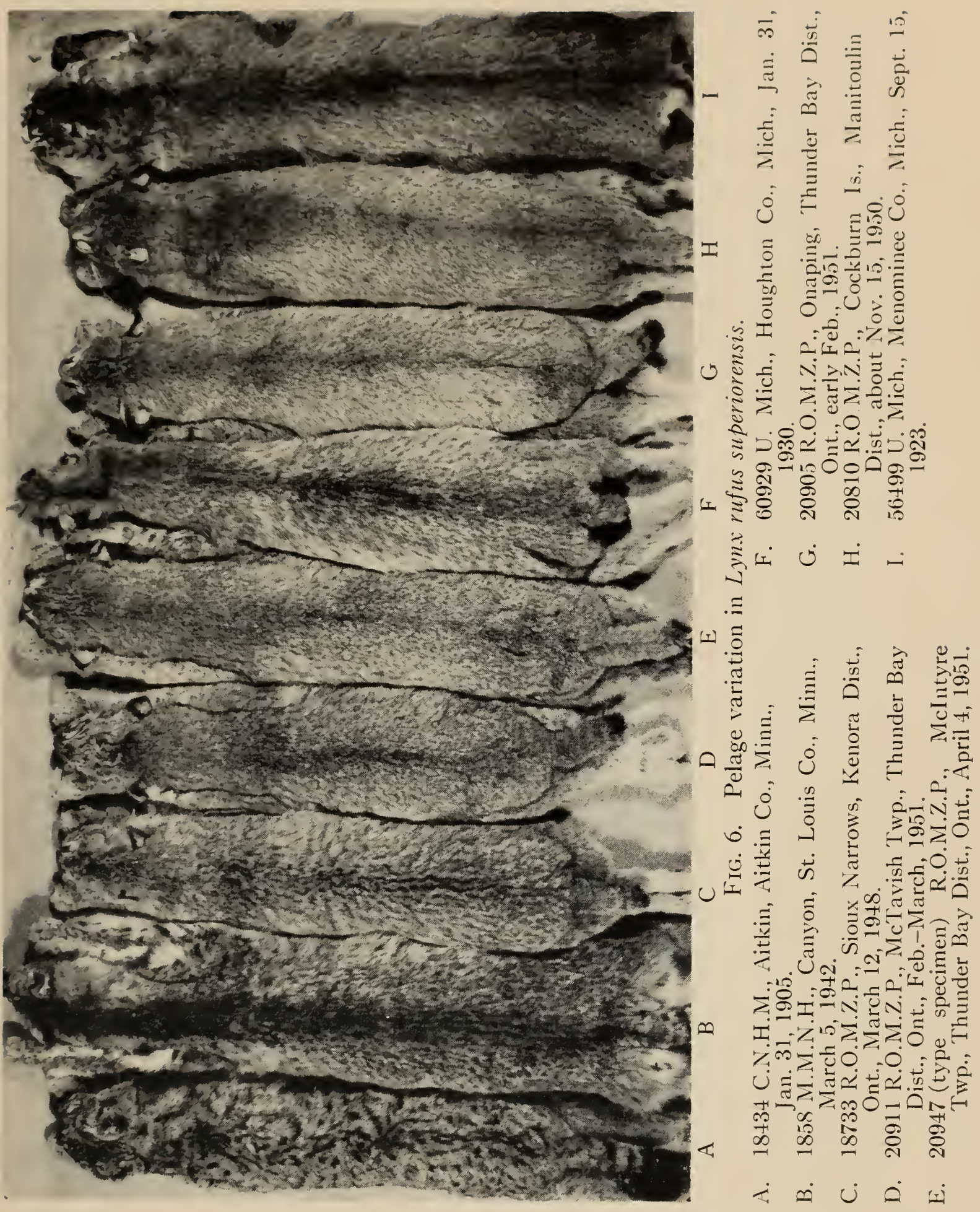


coloration as well as by the texture of the fur, that of the summer being consistently much darker and more reddish in colour, lacking the characteristic hoary appearance of winter specimens.

When arranged from the lightest and grayest inclividuals to the darkest and reddest, we find no correlation in the coloration of winter skins that might be attributed to degree of wear as the season progresses (November to April). Approximately onehalf of the series falls within a grayish group and the other half in a reddish group. The point of division, however, is not sharply marked. The type specimen falls near the middle of the series (fig. 6, E) but within the gray group. In the gray series four specimens show well defined dark markings on the back, while seven are immaculate ashy-gray in appearance. All the spotted individuals are females while of the immaculate gray specimens two are females, two are males, and one is unsexed. Whether or not this observed ratio represents a predominance of spotting in females or merely the results of chance sampling we cannot determine at present. Rather indistinct spotting was observed in four males taken in summer (see fig. 6, I). In the gray series there is a preponderance of younger individuals which further suggests the possibility that age variation may also be influencing our series. The gray end of the series approaches some individuals of pallescens, but in general the latter is much paler.

In our reddish winter group only one out of eleven shows any evidence of spotting on the back. In this case (a young female) the spots are smaller, less distinct and are brownish in colour (see fig. 6, F). In this series, the lightest individuals have a hoary appearance created by whitish bands on the guard hairs all of which appear to have a fine, black, terminal tip. Progressing toward the darker and redder specimens, the light band of the hairs becomes more buffy in colour and the reddish underfur shows through more conspicuously.

In our total series of superiorensis, there seems to be a correlation between light-coloured feet and age. Apparently the whitish feet of younger animals tend to become more buffy with age. In our young animals the hind feet appear almost silvery white, particularly in the gray series. Nevertheless these light-coloured feet are also found in the youngest of the red group (notice fig. 6, C, D and G). In general, both black and white markings appear more intense in superiorensis than in rufus, especially on the feet and legs.

Unfortunately our series of L.r.rufus skins is too small to 
permit critical comparison. In the small series available ( $S$ ) none approaches the gray end of the series of superiorensis and all lack the well defined markings found in some of the latter. One of this group appears grayer than the rest but is much darker than the newly-described race. There is also one specimen which shows small, indistinct markings on the back, and another in which there is a tendency for the mid-dorsal stripe to break up into spots. Although only one or two of our rufus series can be considered as young individuals, none shows the whitish feet commonly found in the young of superiorensis.

In general, however, our rufus specimens approach closely the reddish end of our superiorensis series. The pelage of the latter seems to have a somewhat softer texture, being longer and thicker, although not as soft as in pallescens, nor as long as in gigas.

In our series of 12 gigas skins we also find considerable variation in general coloration, although none shows distinct markings on the back. This form has a more hoary appearance than either rufus or superiorensis, and usually has a greater admixture of black on the back. Certain individuals from Nova Scotia can be matched quite closely with certain specimens of rufus, while others approach superiorensis.

Cranial measurements. In table I the average and observed limits of various skull measurements are given for the adult males examined.

External measurements. In table II measurements and weights of roughly comparable specimens are presented. Garnier (1882b) records the total length and weight for ROMZP specimen no. 91-11-1-76 as well as 91-11-1-80 and gives additional data for Ontario specimens of $L$. $r$. gigas. The former, listed as 68.5 pounds, seems almost incredible; however, the total length of $1252 \mathrm{~mm}$. and the size of the skull (greatest length $149.5 \mathrm{~mm}$.) seem to attest the gigantic size of this specimen (see fig. 3, I, fig. 4, C). Specimen $91-11-1-80$ is listed by Garnier (op. cit.) as a young female from Wawanosh Township with a total length of 38 inches $(96.5 \mathrm{~mm}$.) and weight of 30 pounds. He also records an adult female from Culross Township with a weight of 53 pounds (total length 48 ins. or $1219 \mathrm{~mm}$.); a young male from Ashfield Twp. (27 lbs.; 959 mm.); an adult from Kent Co. (35 lbs.; 1022 mm.); and a young specimen from Lucknow Twp. (2.5 lbs. ; $965 \mathrm{~mm}$.).

Remarks. Unfortunately we have not been able to add much to the knowledge of sex and age variation in cranial characters 
Table I. Cranial measurements of northeastern adult male bobcats. The mean is followed by the number of specimens averaged and the observed limits are given below in brackets.

Greatest length

Condylobasal length

Length of palate

Zygomatic breadth

Mastoid breadth

Height of cranium

Interorbital breadth

Postorbital constriction

Postorbital process

Maxillary toothrow

Length $\mathrm{PM}^{3-4}$

Length $\mathrm{PM}^{3}$

Width $\mathrm{PM}^{3}$

Length $\mathrm{PM}^{4}$ (buccal)

Width $\mathrm{PM}^{4}$

Greatest width of palate including toothrows

Least width of palate between premolars

Least width between bullae

$\frac{\text { L. r. rufus }}{131.9(18)}$
$(119.8-142.6)$
$120.4(18)$
$(108.9-130.2)$

$52.9(17)$

(46.2-58.5)

$95.0(13)$

(84.3-107.1)

$56.0(18)$

(49.9-61.5)

$46.0(7)$

(43.5-48.2)

$25.1(16)$

(21.8-27.6)

$38.0(17)$

(35.4-41.3)

60.1 (13)

(53.8-71.1)

$$
38.3(7)
$$

(35.9-40.5)

$24.6(7)$

(22.7-26.4)

$9.80(7)$

(9.1-10.4)

\section{$5.47(7)$}

(4.9-5.8)

$14.3(18)$

(13.0-16.0)

$6.80(18)$

(5.6-7.9)

$51.8(17)$

(46.3-57.5)

$27.4(7)$

(24.9-30.1)

$13.8(7)$

(11.8-15.6)

$7.70(7)$

Upper canine diameter

(at alveolus, anteroposteriorly) (7.1-8.2)

Width of rostrum across canines $\begin{array}{cc}\text { L. r. superiorensis } & \text { L. r. gigas } \\ 134.2(15) & \frac{137.1(10)}{(126.2-142.6)}(131.7-149.5)\end{array}$

$$
123.8(15)
$$

(117.1-133.7)

$125.5(9)$

(121.5-135.0)

$$
53.9(13)
$$

$(51.6-59.4)$

$55.4(10)$

(52.6-61.0)

$95.9(13)$
$(89.4-103.7)$

$94.3(8)$

(88.0-102.3)

$58.5(14)$

(55.6-61.8)

$58.3(9)$

(55.0-61.7)

46.3 (14)

(44.6-48.7)

$47.4(9)$

(44.3-50.7)

$25.8(14)$

$26.0(10)$

(22.4-28.6)

(22.0-29.5)

38.2 (14)

$38.0(10)$

(35.3-41.1)

(35.9-41.0)

61.7 (13)

64.0 (10)

(56.4-66.4)

(56.3-70.9)

38.9 (14)

39.8 (10)

(36.2-40.8)

(38.2-43.1)

24.6 (14)

25.1 (10)

(22.1-26.0)

(23.6-26.3)

$9.86(14)$

$10.2(10)$

(8.8-10.7)

(9.5-10.8)

$5.13(14)$

(4.2-5.7)

$5.27(10)$

(4.8-5.6)

$15.0(15)$

(13.9-16.0)

$15.3(10)$

(14.9-16.0)

$7.04(15)$

(6.1-7.8)

$7.21(10)$

(6.7-7.5)

53.7 (12)

(51.3-57.2)

$52.9(9)$

(49.0-55.5)

$28.8(12)$

(26.6-31.4)

27.7 (9)

(26.8-30.0)

$14.6(13)$

(12.8-16.7)

$14.0(9)$

(12.5-15.6)

$7.66(13)$

(6.8-8.4)

$8.00(10)$

(7.1-8.5)

35.1 (13)

(31.7-38.0)
34.8 (9)

(32.0-37.6) 
Table II. Body measurements (mm.) and weights of adult bobcats.

\begin{tabular}{|c|c|c|c|c|c|c|c|}
\hline Locality & 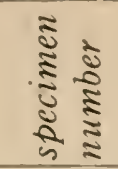 & 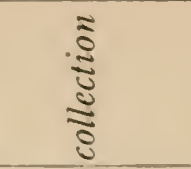 & 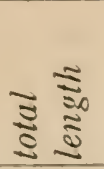 & $\sqrt[3]{3}$ & $\underset{\stackrel{\Xi}{\Xi}}{\stackrel{\Xi}{\Xi}}$ & ปे & 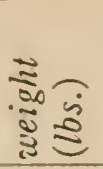 \\
\hline \multicolumn{8}{|c|}{ Lynux rufus rufus ox $0^{x}$} \\
\hline $\begin{array}{l}\text { orest County, Pa. } \\
\text { Sandisfield, Berkshire Co., }\end{array}$ & 1256 & Carn. M. & 810 & 145 & 165 & & \\
\hline Mlass. & +2070 & M.C.Z. & 817 & 144 & 161 & 67 & \\
\hline Arden, Orange Co., N.Y. & 4825 & N.Y.S.M. & 826 & 140 & 158 & & 26.0 \\
\hline Arden, Orange Co., N. I. & 4826 & N.Y.S.M. & 920 & 145 & 165 & 70 & 21.5 \\
\hline $\begin{array}{l}\text { Hancock, Addison Co., Vt. } \\
\text { S. Sandisfield. Berkshire Co. }\end{array}$ & 42077 & M.C.Z. & 939 & 142 & 181 & 77 & 35.0 \\
\hline Mass. & 42071 & M.C.Z. & 946 & 154 & 188 & 76 & \\
\hline
\end{tabular}
Mass.

Lynx rufus superiorensis $\sigma^{7} \sigma^{7}$

Limestone Twp., Alger Co.,

$\begin{array}{llllllll}\text { Nich. } & 60933 & \text { U. Nich. } & 890 & 130 & 180 & 64 & 16.0\end{array}$

McIntyre Twp., Thunder Bay

$\begin{array}{lllllll}\text { Dist., Ont. (type specimen) } 20947 & \text { R.O.M.Z.P. } \quad 940 & 150 & 190 & 70 & 18.2\end{array}$

Silver Islet, Thunder Bay

Dist., Ont.

13018 R.O.M.Z.P. $940 \quad 165 \quad 178 \quad \ldots \quad \ldots$

Mizpah, Koochiching Co.,

Minn.

1369 M.M.N.H. $\quad 940 \quad 152 \quad 178 \quad \ldots \quad 31.0$

Lake-of-the-Woods Co.,

Minn.

2771 M.M.N.H. $\quad 952 \quad 172 \quad 172 \quad \ldots \quad 22.0$

Buffalo, Mright Co., Minn. 1355 M.M.N.H. $\quad \begin{array}{rlllll}959 & 133 & 190 & 61 & \text {. }\end{array}$

Cockburn Is., Mlanitoulin

Dist., Ont.

21418 R.O.M.Z.P. $1015 \quad 171 \quad 197 \quad \ldots \quad 41.0$

Lynx rufus gigas $\sigma^{\top} \sigma^{\top}$

Malagash, Cumberland Co.,

N.S.

20144 N.M. C.

$\begin{array}{lll}937 & 175 & 223\end{array}$

12722 N.M.C.

$953 \quad 165 \quad 203$

Hants Co., N.S.

1819 N.M.C.

$\begin{array}{lllll}1000 & 190 & \ldots & \ldots & 24.0\end{array}$

15 mi. back of Bear R.,

Annapolis Co., N.S.

(type specimen)

B4951 M.C.Z. $1001 \quad 177 \quad 200$

IVest Talamagouche,

Colchester Co., N.S

Bruce Co., Ont.

20143 N.M.C.

$\begin{array}{lllll}1040 & 179 & 192 & \ldots & \ldots\end{array}$

91-11-1-76 R.O.M.Z.P. 1252

Lynx rufus rufus 우 우

Clinton Co., $\mathrm{Pa}$.

8585 Carn. Mus. $800 \quad 118 \quad 143$

FN3099 Cornell U. $\quad 802 \quad 133 \quad 155 \quad \ldots \quad 13.5$

IVestern Mass.

White Sulphur Springs,

Greenbrier Co., IV. Va.

Western Mass.

B5706 M.C.Z.

$\begin{array}{lllll}815 & 148 & 160 & 70 & \ldots\end{array}$

Hancock, Addison Co., Vt. 42079 M.C.Z.

Hancock, Addison Co., Vt. 42075 M.C.Z.

Debar Mt. Refuge,

Franklin Co., N.Y.

4826 N.Y.S.M.

$\begin{array}{lllll}817 & 136 & 157 & \ldots & 14.5\end{array}$

$\begin{array}{lllll}824 & 144 & 157 & 71 & 12.75\end{array}$

$\begin{array}{lllll}847 & 147 & 169 & 76 & \ldots\end{array}$

Lynx rufus superiorensis 우 우

Watersmeet, Gogebic Co.,

$\begin{array}{llllllll}\text { Mich. } & 60932 & \text { U. Mich. } & 800 & 130 & 165 & 63 & 16.0\end{array}$

Canyon, St. Louis Co., Minn. 1858 M.M.N.H. $\begin{array}{llllll}843 & \ldots & 156 & 75 & \text {. }\end{array}$

Sioux Lookout, Kenora Dist., Ont.

Cockburn Is., Manitoulin Dist., Ont.

Sifton Twp., Rainy River Dist., Ont.

Cockburn Is., Manitoulin Dist., Ont.

$\begin{array}{lllllll}20905 & \text { R.O.M.Z.P. } & 855 & 131 & 170 & 68 & \ldots \\ 21357 & \text { R.O.M.Z.P. } & 862 & 140 & 180 & \ldots & 27.0 \\ 18020 & \text { R.O.M.Z.P. } & 881 & 129 & 168 & \ldots & 17.5 \\ 20810 & \text { R.O.M.Z.P. } & 900 & 152 & 178 & \ldots & \ldots\end{array}$


beyond that outlined by Grinnell and Dixon (1924) for western bobcats. Our male series seems to include a normal progression from very young to very old individuals, while our females apparently lack any representation between what we tentatively regard as young adults and truly old individuals, if the development of the sagittal crest, size and suture closure are used as age criteria.

Examination of a series of 25 skulls of pallescens and measurements of over 75 additional specimens show a normal progression from quite young to very old individuals in both sexes. In 37 adult males, the greatest length of the skull averaged $133.0 \mathrm{~mm}$. (122.3-144.2) whereas 24 females averaged 126.5 (118.9-137.4). Of superiorensis females, we have a series of 11 specimens (from young adult to apparently mature individuals) with the greatest length of skull averaging $119.9 \mathrm{~mm}$. (116.5-123.2) and in addition a single large female of $137.4 \mathrm{~mm}$. Similarly in rufus we have 17 individuals averaging 114.2 (107.2-123.1) and three large females which measure respectively $128.5,131.2$ and 134 .4. Of six gigas female skulls available, three are juveniles, two are young adults (skull damaged in one) and only one is a mature individual (136.4 mm. greatest length).

A larger series of specimens is required to properly define sexual variation of eastern bobcats, especially with respect to adult females.

Explanations. Most cranial measurements used were taken in the conventional manner except in the case of the length of the palate. In this case we have measured from the median posterior extension of the palate to, and including, the median incisors.

Dr. J. K. Doutt of the Carnegie Museum in Pittsburgh has kindly made available to us the cranial measurements of bobcats in most of the larger museums in eastern North America, taken by him a few years ago. In cases where the same specimens have been measured by Doutt and the writers, the results show striking uniformity.

The following abbreviations have been used:

A.M.N.H.-American Museum of Natural History

B.S.C.-Biological Surveys Collection, Fish and Wildlife Service, U.S. Department of the Interior

Carn. M.-Carnegie Museum, Pittsburgh

C.N.H.M.-Chicago Natural History Museum

Cornell U.-Cornell University, Department of Conservation

M.C.Z.-Museum of Comparative Zoology, Harvard University

M.MI.N.H.--Minnesota Museum of Natural History 
N.M.C.-National Museum of Canada

N.Eng.M.N.H.-New England Museum of Natural History, Boston

N.Y.S.M.-New York State Museum, Albany

R.O.M.Z.P.- Royal Ontario Museum of Zoology and Palaeontology

U. Kan.-University of Kansas, Museum of Natural History

U. Mich.-University of Michigan, Museum of Zoology

Specimens examined. Bobcats from most of North America were considered by us in this study; however, only those from the eastern sections are listed below. Specimens measured by Dr. Doutt and not actually seen by us are indicated by an asterisk $(*)$. A total of 226 specimens from the east was used, 124 examined by ourselves and 102 by Dr. Doutt as follows:

Alabama, 1: Clarke Co., 1 (U. Mich.).

Connecticut, 15: Litchfield Co., 13* (M.C.Z.), 1* (A.M.N.H.) and Hartland [?], 1* (M.C.Z.).

Florida, 5: Collier Co., 2* (A.M.N.H.); Palm Beach Co., 1* (M.C.Z.); Pinellas Co., 1* (A.M.N.H.) and no definite locality, $1^{*}$ (A.M.N.H.).

Georgia, 1: Okefenokee Swamp, 1* (A.M.N.H.).

Kentucky, 1: Trigg Co., 1 (U. Mich.).

Louisiana, 10: Madison Parish, 6* (B.S.C.); near Rouge [?], 2* (M.C.Z.); Tensas Bayou, 1* (B.S.C.) and Vermelion Parish, 1* (B.S.C.).

Maine, 31: Aroostook Co., 1* (M.C.Z.); Piscataquis Co., 1* (N.Eng.M.N.H.); Hancock Co., 1 (C.M.N.H.), 1 plus 9* (M.C.Z.); Washington Co., 1* (N.Eng.M.N.H.), 4 plus $9^{*}$ (M.C.Z.); no definite locality, $1^{*}$ (A.M.N.H.) plus $1^{*}$ (M.C.Z.); Pemberton [?], 1* (M.C.Z.) and West Otis [?], 1* (M.C.Z.)

Massachusetts, 11: Berkshire Co., 3* (M.C.Z.); Essex Co., 1* (N.Eng.M.N.H.); Middlesex Co., 1* (M.C.Z.); Worchester Co., 2* (M.C.Z.); Bane [?], 1* (M.C.Z.) and Western Mass. (no def. loc.), 3 (Cornell U.).

Michigan, 41-Lower Peninsula, 5: Alcona Co., 1 (U. Mich.); Montmorencey Co., 2 (U. Mich.); Oscoda Co., 1 (U. Mich.) and Presque Isle Co., 1 (U. Mich.)-Upper Peninsula, 36: Alger Co., 4 (U. Mich.); Baraga Co., 3 (U. Mich.); Chippewa Co., 2 (U. Mich.) plus 2 (R.O.M.Z.P.); Dickinson Co., 1 (U. Mich.); Gogebic Co., 8 (U. Mich.); Houghton Co., 2 (U. Mich.); Keweenaw Co., 1 (U. Mich.); Marquette Co., 4 (U. Mich.), 1 (C.M.N.H.) and $1^{*}$ (B.S.C.); Menominee Co., 2 (U. Mich.); Ontonagon Co., 3 (U. Mich.); Schoolcraft Co., 1 (U. Mich.) and Upper Peninsula (no def. loc.), 1 (U. Mich.)

Minnesota, 15: Aitkin Co., 1 (C.M.N.H.); Benton Co., 1* (B.S.C.); Koochiching Co., 1 (M.M.N.H.); Lake-of-the-Woods Co., 1 (M.M.N.H.); Red Lake Co., 2 (M.M.N.H.); Roseau Co., 1 (M.M.N.H.); St. Louis Co., 3* (A.M.N.H.), 1 (U. Kans.) and 1 (M.M.N.H.); Wright Co., 1 (M.M.N.H.); and no definite locality, 2 (M.M.N.H.).

Missouri, 4: Banner [?], 4* (B.S.C.).

Mississippi, 1: no definite locality, 1 (C.N.H.M.).

New Brunwsick, 3: York Co., 2 (N.M.C.) and 1* (A.M.N.H.).

New Hampshire, 5: Coos Co., 1 (M.C.Z.) plus 1* (N.Eng.M.N.H.); Merrimack Co., 1 (M.C.Z.) plus 1 (U. Kans.); Sullivan Co., $1^{*}$ (N.Eng.M.N.H.).

New York, 11: Adirondack Mts., 2 (Cornell U.); Dutchess Co., 1 (N.Y.S.M.); Franklin Co., 1 (Cornell U.) plus 2 (N.Y.S.M.); Shoharie Co., 1 (N.Y.S.M.); and Warren Co., 1 (N.Y.S.M.). 
North Carolina, 5: Cumberland Co., 1* (A.M.N.H.); Montgomery Co.. $1^{*}$ (M.C.Z.); near Mt. Mitchell, 2* (M.C.Z.) and no definite locality; 1* (A.M.N.H.).

Nova Scotia, 12: Annapolis Co., 1 plus 1* (M.C.Z.); Colchester Co., 2 (N.M.C.) and no definite locality, 2 (N.M.C.).

Ontario, 24 (unless otherwise designated specimens are in the R.O.M.Z.P.): Southern Ontario, 5: Bruce Co., 2; Huron Co., 1; Simcoe Co., 1 (N..I.C.) and York Co., 1-Central Ontario, 7: Algoma Dist., Twp. 22, Range 14, 1; Manitoulin Dist., Cockburn Is., 6-Northwestern Ontario, 13: Cochrane Dist., English River Post, 1; Kenora Dist., Sioux Narrows, 1; Rainy River Dist.-Sifton Twp., 1, Dewart Twp., 1, Ft. Francis, 1 and Lac la Croix, 1; Thunder Bay Dist.-McIntyre Twp., 1, McTavish Twp., 3, Onaping, 1, Silver Islet, 1 and Whitefish Lake, 1.

Pennsylvania, 4: Cameron Co., 1* (B.S.C.); Clinton Co., 1 (Carn. M.); Forest Co., 1 (Carn. M.) and northern part, 1* (M.C.Z.).

South Carolina, 2: Aiken Co., 1* (A.M.N.H.) and Richard Co. 1* (M.C.Z.).

Vermont, 16: Addison Co., 3 plus 5* (M.C.Z.); Bennington Co., 1 plus 1* (M.C.Z.); Windsor Co., $1^{*}$ (B.S.C.) plus $2^{*}$ (M.C.Z.) and no definite locality, 3 (Cornell U.).

Virginia, 4: Bath Co., 1* (B.S.C.); Nansemond Co., 1*(A.M.N.H.) and Dismal Swamp, 2* (A.M.N.H.).

West Virginia, 2: Greenbrier Co., 2* (M.C.Z.).

Wisconsin, 1: Villas Co., 1 (C.N.H.M.).

\section{Notes on the Distribution of Eastern Bobcats}

Several authors have felt that gigas would probably prove to be a subspecies of rufus. Among specimens examined from southeastern Maine, extreme northern New Hampshire and Vermont, and southwestern New Brunswick, some seem to be clearly referable to gigas, some to rufus, and others appear intermediate. One specimen from Fort Covington, New York, also approaches gigas. All other specimens to the immediate south of this area seem clearly assignable to rufus on the basis of skull characters. Of eastern bobcats, rufus proves to have the relatively widest skull and is bounded on both the north and south by the relatively narrow-skulled races, gigas and floridanus (see fig. 1, D). On the basis of this character, specimens from extreme southeastern Virginia and southward along the Atlantic seaboard all seem referable to floridanus.

Cranial measurements of four specimens from southeastern Missouri indicate that the form of that region is not rufus. The skulls are a relatively narrow type, more akin to floridanus or possibly texensis. Unfortunately we have been unable to determine by what cranial characters, if any, texensis can be distinguished from floridanus.

Specimens from the Gulf Coast of Texas (Corpus Christi, 
7 examined; Rockport, 2; and Brownsville area, 10) are strikingly similar in basic cranial measurements to floridanus.

A single skin examined from Trigg County, Kentucky, though not diagnostic, we tentatively regard as floridanus on the basis of its isolation from the present known range of rufus and its proximity to the narrow-skulled animals from southeastern Missouri.

We have examined a single skull and a single skin without skull from northeastern Kansas which we cannot satisfactorily assign to any of the eastern races. The skin (from near Junction City, Geary Co., Kansas) is in summer pelage. It has been salted and tanned and is not sufficiently diagnostic to be identified with certainty. The skull, however (from near Lawrence, Douglass Co., Kansas), differs markedly from any rufus specimen seen by us. It is not of the floridanus type; compares favourably in dental characters with superiorensis; but its bulla is unlike the latter, comparing more favourably with pallescens or some related western form. The same is true of skulls examined from both North Dakota (Billings Co., 1) and South Dakota (Pennington Co., 3; Custor Co., 1; and Dewey Co., 3). It appears possible that the bobcats of the plains region of the central United States may represent an undescribed race. Dr. IV. B. Davis reaches similar conclusions (in manuscript).

At present the nominate race, L. r. rufus, appears to be restricted mainly to the United States, from the Appalachian Mountains northeastward to southern Maine, southwestern New Brunswick and possibly extreme southern Quebec with a now isolated population in the lower peninsula of Michigan. The unstable nature of the upper peninsula specimens suggests the possibility of some past intergradation between the upper and lower peninsula populations.

L. r. floridanus apparently occupies the lower coastal areas of all the southeastern states and up the adjacent sides of the Mississippi River, possibly as far north as southern Illinois.

L. r. gigas is presently known to occur in Nova Scotia, northern and eastern New Brunswick and northern Maine. We have been unable to locate any specimen of bobcats from southern Quebec. All available specimens from southern Ontario attest to a former connection with the present known range. Without recent specimens (none since 1906) it seems possible that the former gigas population may now be extinct in southern Ontario or that it may have been replaced by a more recent invasion of $L$. r. rufus (see below). 


\section{A Review of the Distribution and Status OF BOBCATS in ONTARIO}

In both time and space the distribution of the bobcat ( $\operatorname{Lyn} x$ rufus) in Ontario presents an interesting picture. The pattern of distribution, as we have been able to work it out from the literature, trappers' reports and the study of specimens, apparently represents a recent northern extension of range into Ontario which several other species have exhibited. Although differing in detail and extent, the basic pattern of this distribution is similar to that which Peterson (1950) found for the moose in Ontario.

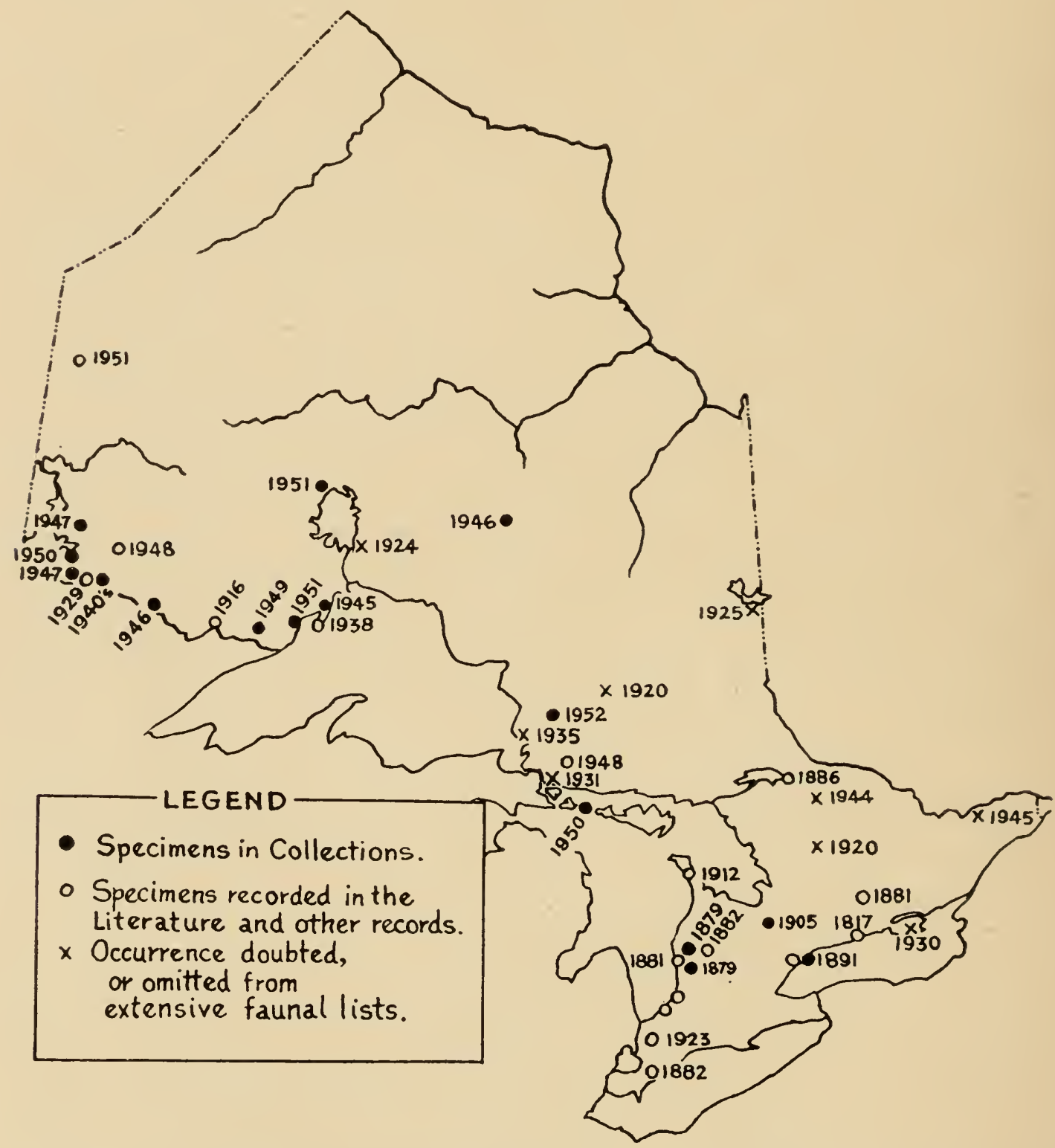

FIG. 7. Map of Ontario showing distribution and spread of bobcats, with dates of records. 
Ontario, apparently, has received its bobcat populations from two main sources and at three different times. In eastern Ontario, south of a line from Georgian Bay to the eastern end of Lake Ontario, the bobcat has been present since historical times. It was of fairly regular occurrence up to the end of the last century. Since then it has apparently declined steadily and our attempts to secure current specimens have met with failure, although persistent reports of their presence have been received.

It was unknown in the western half of the Province until thirty or forty years ago when trappers first reported this strange new cat in the southern part of the Rainy River District. Since then it has spread north and east, at least as far as twenty miles east of the Hudson's Bay Company's English River Post, Cochrane District, where in 1946 a female was taken by local trappers (Peterson and Crichton, 1949). The most recent event in the invasion of Ontario by the bobcat has been the crossing over from the upper peninsula of Michigan, to Cockburn Island in Manitoulin District, and the southern portion of Algoma District. This apparently has taken place within the last four or five years. All available evidence indicates that these three populations (see fig. 7) are not as yet in contact with each other. Peterson and Crichton (1949) received reports of four bobcats having been taken in the Chapleau District between 1919 and 1942, although positive identification of these animals remains in doubt. Extensive trapping in this area since 1942 has failed to reveal a single specimen.

With the exception of Seton's (1925, p. 218) account of examining several skins taken near Lake Nipissing in 1886, all the eastern specimens and published records of occurrence are confined to the southwestern half of southeastern Ontario, reaching the northern limits in Bruce Peninsula (Klugh, 1912) and the eastern limits in Peterborough County (Clementi, 1881). Other evidence, however, seems to invalidate an assumption that the above boundaries represent the actual range in southeastern Ontario. If the range was thus limited it might suggest that the animals entered Ontario around Lake Erie from an area occupied at the present time by L. rufus rufus. The racial affinities of historic Ontario specimens, however, are with $L$. $r$. gigas to the east. This suggests, that at least formerly, gigas extended from Nova Scotia to southern Ontario. The fact that all the Ontario specimens of gigas were taken prior to 1906, leaves the possibility that rufus may have moved in from the south within the last half century and replaced gigas in the 
western part of its range. Some support for this is found in the most northerly specimen examined from New York State. This specimen, taken in 1946 just south of the St. Lawrence River, shows some signs of intergradation between rufus and gigas.

The evidence for the absence of the species in the area around the eastern end of Lake Ontario is circumstantial, based on its omission from several lists of mammals from areas within this general region. Small and Lett (1888) in writing of the mammals of the Ottawa region, state, "There is great doubt if the wild-cat is found here at all." Rand (1945) writing of the same region, omits it from his list of fifty-four species, past and present. Snyder (1941) does likewise in his faunal survey of Prince Edward County. Downing (1944) found no records for Algonquin Park, and Anderson (1938, p. 70) states that in Quebec the bobcat is found only south of the St. Lawrence River, although we know of no actual specimen from that region.

The present status of Lynx rufus in southeastern Ontario is not clear. "Wild-cats" are reported from time to time but thus far the identity of the animal involved was either in doubt or definitely not bobcat. The Ontario Department of Lands and Forests has cooperated with the Museum in an attempt to secure specimens and authentic records of Ontario bobcats. Many hunters and trappers were contacted and several bobcats were secured from western Ontario, but none from the east. An inquiry made of the larger fur dealers in eastern Ontario indicated that none of these had secured a bobcat skin during the trading season of 1950-51. On the other hand, we have had persistent reports of the recent occurrence of the animal from reliable sources which would indicate that, although rare, some form of the bobcat persists, and may even be on the increase.

The decline of the bobcat in southeastern Ontario is chronicled in the writings on Ontario mammals. Garnier (1882a) speaks of it as being not uncommon in the Bruce Peninsula in the 1880's; Miller (1897) says it still occurs at Mount Forest, Wellington County; Fleming (1913) records it as never being common at Toronto; Soper (1923) writing of Wellington and Waterloo Counties records it as of probable rare occurrence; Snyder (1930) reporting on King Township, York County, says Lynx rufus probably occurred in earlier days; Snyder (1931) mentions a 1926-27 sight record of the species in Norfolk County; and Saunders (1932) expresses the belief that it still persists in the Georgian Bay area. He also records a specimen shot near Sarnia in 1923. 
Although Anderson (1947, pp. 76-77) does not include western Ontario or Manitoba in the range of Lynx rufus, Seton (1925, pp. 218-220) in support of his statement that the bobcat has been moving north with the advance of agriculture, produces some evidence to suggest that the bobcat had moved into southern Manitoba by the early part of the present century. The first specimen recorded from western Ontario was one supposedly taken near Northern Light Lake just north of the Ninnesota border in 1916 (Cahn, 1937). There are no further reports of the species from this general area until the 1920's or 1930 's when it apparently started to increase and spread rapidly northward. Johnson (1922) writing of Lake County, Minnesota, reports it as present but scarce. The same author (1930) later records it as extending its range in the eastern section of northwestern Minnesota. Snyder (1938) reporting on a faunal investigation of western Rainy River District in 1929 speaks of a local resident trapping a strange new cat which, from the description, is almost certainly Lynx rufus. Dymond (1928) reporting on the Lake Nipigon region (now within the range of the bobcat) for the years 1921-24, does not mention the species in his fairly exhaustive list.

From the 1920's or 30's on, the bobcat has increased steadily in numbers in western Ontario and spread further and further north and east. This development has been marked by reports of trappers taking this new animal in increasing numbers in their trap-lines. For example, Mr. Bob Howard, trapping near Crow Lake, Kenora District, caught his first bobcat in the winter of 1948-49. He took nine the following winter and four in 1950-51. These reports, in the main, have been substantiated by specimens sent to the Museum and at the present time the extremes of this range extension as marked by specimens in the Museum collection, are a female taken in 1946, twenty miles east of the Hudson's Bay Company's English River Post, Cochrane District, and a second female taken near Onaping, Thunder Bay District, in 1951. Officials of the Sioux Lookout District, Department of Lands and Forests, report that a bobcat was caught in the vicinity of Pekangikum, northwest of Red Lake in 1950-51, although no specimen was preserved. This would apparently mark the northern limit in the western part of its known range. Norris-Elye (1951) reports the first specimen for Manitoba which seems to indicate the western limit of range in Canada. This was again a female, taken near Mud Lake, southeastern Manitoba, in 1951. Although this was the first 
animal to reach the attention of a scientific institution, local residents report the species as first appearing in the area about eight years ago.

We are indebted to Dr. A. de Vos of the Department of Lands and Forests and Mr. H. McQuarrie of Gore Bay, Ontario, for the history of the most recent development in the range extension of the bobcat. Since January, 1951, the Museum has received six specimens of Lynx rufus from Mr. McQuarrie, all taken on Cockburn Island, western Manitoulin District, between November, 1950 and October, 1951. In addition, Mr. McQuarrie made inquiries of the local trappers from whom he received the specimens and they are all in agreement that the bobcat was new to the district, first appearing about 1948. That it reached the mainland in Algoma District, Ontario, about the same time is indicated by the trapping records of Mr. J. W. H. Taylor, supplied by Dr. de Vos. Mr. Taylor, whose trap-line lies in Gillmor Township about 35 miles east and north of Sault Ste. Marie, trapped his first bobcat in the winter of 1948-49, three the following winter, and five in 1950-51. In January, 1952, we received our first specimen for the Algoma District, taken some 40 miles north of the above recorded locality. Circumstantial evidence that these animals came from the west rather than the north around Lake Superior is provided by Manville (1950), Snyder (1942) and Clarke (1937). The former records the bobcat as present on Drummond Island, Michigan, in 1948-49, while the latter two authors omit the species in their respective reports of faunal surveys conducted in the Sault Ste. Marie area by Snyder in 1931 and the Pancake Bay area by Clarke in 1935. Their racial affinities with upper peninsula of Michigan specimens rather than with gigas specimens from the Bruce Peninsula, rules out an invasion from the east.

In summary, two races of bobcats have occupied three distinct areas in Ontario. The two western populations of superiorensis entered Ontario in recent times from Minnesota and the upper peninsula of Michigan respectively and are apparently expanding their range. If present trends continue they should meet in the near future and probably spread to southeastern Ontario. In the latter area, the present status of the species is not clear. Present since historical times, it reached a very low point by the turn of the century. Early specimens are referable to gigas but there is the possibility a northward movement of rufus into Ontario from the south may have taken place.

The question of the ecological relations between Lynx rufus 
and Lynx canadensis, particularly in western Ontario and the Sault Ste. Marie-Manitoulin region, presents an important problem which should be studied closely. The Canada lynx, which has remained at a precariously low population level, may be in the process of being replaced in the southern part of its range by these invasions of bobcats from the south.

\section{ACKNowledgatents}

We are indebted to a great number of people for much kind cooperation in making this study possible. We are especially grateful to Dr. J. K. Doutt, of the Carnegie Museum in Pittsburgh who kindly made available to us the results of a great effort on his part to accumulate the measurements of bobcats taken in most of the larger museums in eastern North America. His data has greatly facilitated the completion of this study. We are also indebted to Dr. Doutt and the Carnegie Museum for the loan of specimens.

We especially wish to acknowledge the assistance and cooperation of Mr. Austin Cameron of the National Museum of Canada who not only lent us their entire collection but also graciously permitted us to carry out a problem that he had anticipated on the taxonomic status of gigas.

The Ontario Department of Lands and Forests through the the offices of the Fish and Wildlife Division (especially Dr. IV. J. K. Harkness, Dr. C. H. D. Clarke and Dr. A. de Vos) greatly assisted this study through a province-wide effort to obtain Ontario bobcat specimens, and the provision of other data.

Dr. W. B. Davis of the Agricultural and Mechanical College of Texas kindly provided us with an unpublished manuscript covering a review of bobcats in the western United States.

Mr. H. McQuarrie provided an outstanding service by securing for us a series of specimens from the Manitoulin District as well as important data on the recent spread of this animal into that area.

We wish to acknowledge our sincere thanks to the following persons and institutions for the loan of specimens and other courtesies extended to us:

Mr. C. C. Sanborn, Chicago Natural History Museum

Dr. W. J. Hamilton, Cornell University

Dr. C. P. Lyman, Museum of Comparative Zoology

Dr. W. J. Breckenridge, Minnesota Museum of Natural History 
Dr. R. S. Palmer, New York State Museum

Dr. R. H. Baker, University of Kansas

Dr. W. H. Burt, University of Michigan

Dr. Philip L. Wright, University of Montana

Dr. Don C. Quimby, Montana State College

\section{Literature Cited}

Anderson, R. M.

1938. Mammals of the Province of Quebec. Ann. Report of the Provancher Soc., pp. 50-103.

1947. Catalogue of Canadian Recent mammals. Natl. Mus. Can., bull. Brooks, A. no. 102 , biol. ser. no. 31, pp. 1-238.

1905. The mammalia of northern Wellington. Ont. Nat. Sci. Bull., no. 1, pp. 25-26. (8 numbers, pub. annually, 1905-1913, Wellington Field

CAHN, A. R. Nat. Club, Guelph, Ont.)

1937. The mammals of the Quetico Provincial Park of Ontario. Jour. Mamm., vol. 18, no. 1, pp. 19-30.

Clarke, C. H. D.

1937. A study of the mammal population of the vicinity of Pancake Bay, Algoma District, Ontario. Natl. Mus. Can., bull. 88, pp. 141-152.

Clementi, $\mathrm{V}$.

1881. Rara Felis. The Canadian Sportsman and Naturalist, vol. 1, no. 4. p. 28. (3 vols. pub. monthly at Montreal, Que., 1881-83).

Downing, S. C.

1944. The mammals of Algonquin Park. Mimeographed, Roy. Ont. Mus.

DYMOND, J. R. Zool., Toronto, pp. 1-8.

1928. The mammals of the Lake Nipigon region. in A faunal investigation of the Lake Nipigon region, Ontario. (by Dymond, J. R., et al.). Trans. Roy. Can. Inst., vol. 16, pt. 2, pp. 233-291 (pp. 234-250).

Fleming, J. H.

1913. The mammals. in The natural history of the Toronto region, Ontario, Canada. (by Faull, J. H. [ed.], et al.). Can. Inst., Toronto,

GARNIER, J. H. pp. 1-419 (pp. 206-211).

1882a. Notes on the natural history of Lucknow, Ont. The Can. Sportsman and Nat., vol. 2, no. 4, pp. 125-126.

1882b. Lynx rufus - the red lynx. The Can. Sportsman and Nat., vol. 2. no. 8, pp. 160-162.

Grinnell, Joseph and Joseph Dixon

1924. Revision of the genus Lynx in California. Univ. Calif. Publ. in Zool., vol. 21, no. 13 , pp. 339-354.

Johnson, C. E.

1922. Notes on the mammals of Northern Lake County, Minnesota. Jour. Mamm., vol. 3, no. 1, pp. 33-39.

1930. Recollections of the mammals of northwestern Minnesota. Jour. Mamm., vol. 11, no. 4, pp. 435-452. 
KLugh, A. B.

1912. Notes on the mammals of the Bruce Peninsula. Ont. Nat. Sci. Bull., no. 7, p). $58-60$.

NANTILLE, R. H.

1950. The mammals of Drummond Island, Michigan. Jour. Mamm., vol. 31 , no. 3 , pl). 358-359.

MERRIAM, C. H.

1890. Results of a biological survey of the San Francisco Mountain Region and Desert of the Little Colorado, Arizona. N. Amer. Fauna no. 3, pp. 1-101.

Miller, G. S., JR.

1897. Notes on the mammals of Ontario. Proc. Boston Soc. Nat. Hist., vol. 28 , no. 1 , pp. $1-44$.

Norris-Elye, L. T. S.

1951. The bay lynx in Manitoba. Can. Field-Nat., vol. 65, no. 3, p. 119.

Peterson, R. L. and V. Crichton

1949. The fur resources of Chapleau District, Ontario. Can. Jour. Res., vol. 27 , sec. D, pp. 68-84.

Peterson, R. L.

1950. A new subspecies of moose from North America. Occ. Pap. Roy. Ont. Mus. Zool., no. 9, pp. 1-7.

RAND, A. L.

1945. Mammals of the Ottawa District. Can. Field-Nat., vol. 59, no. 4, pp. 111-132.

SAUNders, IV. E.

1932. Notes on the mammals of Ontario. Trans. Roy. Can. Inst., vol. 18, pt..2, pp. 271-309.

Seton, E. T.

1925. Lives of game animals. Doubleday, Doran and Co., Garden City, New York, vol. 1, pp. 1-640.

Siall, H. B. and W. P. LetT

1885. Report of the Zoological Branch. Ottawa Field-Nat. Club, Trans. No. 6, vol. 2, no. 2, pp. 280-283.

SNYDER, L. L.

1930. The mammals of King Township. in A faunal investigation of King Township, York County, Ontario. (by Snyder, L. L. and E. B. S. Logier). Trans. Roy. Can. Inst., vol. 17, pt. 2, pp. 167-208 (pp. 173181).

1931. The mammals of Long Point and vicinity. in A faunal investigation of Long Point and vicinity, Norfolk County, Ontario. (by Snyder, L. L. and E. B. S. Logier). Trans. Roy. Can. Inst., vol. 18, pt. 1, pp. 117-236 (pp. 127-138).

1938. A faunal investigation of western Rainy River District, Ontario. Trans. Roy. Can. Inst., vol. 22, pt. 1, pp. 157-213.

1941. The mammals of Prince Edward County, Ontario. in A faunal investigation of Prince Edward County, Ontario. (by Snyder, L. L. et al.). Univ. Tor. Studies, biol. ser., no. 48, pp. 1-123 (pp. 12-24).

1942. Mammals of the Sault Ste. Marie region. in A faunal investigation of the Sault Ste. Marie region, Ontario. (by Snyder, L. L. et al.). Trans. Roy. Can. Inst., vol. 24, pt. 1, pp. 99-165 (pp. 105-120).

SOPER, J. D.

1923. The mammals of Wellington and Waterloo Counties, Ontario. Jour. Mamm., vol. 4, no. 4, pp. 244-252. 

II

$x$

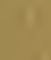

I)

$=$

410 n

\section{,}


512 

LIBRARY

ROYAL ONTARIO MUSEUM 
